\title{
MOBILITY OF INORGANIC AND ORGANIC PHOSPHORUS FORMS UNDER DIFFERENT LEVELS OF PHOSPHATE AND POULTRY LITTER FERTILIZATION IN SOILS ${ }^{(1)}$
}

\author{
Fabrício de Oliveira Gebrim ${ }^{(2)}$, Roberto Ferreira Novais ${ }^{(3)}$, Ivo \\ Ribeiro da Silva ${ }^{(3)}$, Fernanda Schulthais ${ }^{(2)}$, Leonardus Vergütz ${ }^{(2)}$, \\ Lorena Costa Procópio ${ }^{(4)}$, Frederico Fonseca Moreira ${ }^{(4)} \&$ Guilherme $^{2}$ \\ Luiz de Jesus ${ }^{(2)}$
}

\begin{abstract}
SUMMARY
The eutrophication of aquifers is strongly linked to the mobility of $P$ in soils. Although P mobility was considered irrelevant in a more distant past, more recent studies have shown that $\mathrm{P}$, both in organic $(\mathrm{Po})$ and inorganic forms $(\mathrm{Pi})$, can be lost by leaching and eluviation through the soil profile, particularly in less weathered and/or sandier soils with low $P$ adsorption capacity. The purpose of this study was to determine losses of $\mathbf{P}$ forms by leaching and eluviation from soil columns. Each column consisted of five PVC rings (diameter $5 \mathrm{~cm}$, height $10 \mathrm{~cm}$ ), filled with two soil types: a clayey Red-Yellow Latosol and a sandy loam Red-Yellow Latosol, which were exposed to water percolation. The soils were previously treated with four $\mathrm{P}$ rates $\left(\right.$ as $\left.\mathrm{KH}_{2} \mathrm{PO}_{4}\right)$ to reach $0,12.5,25.0$ and $50 \%$ of the maximum $\mathrm{P}$ adsorption capacity (MPAC). The $P$ source was homogenized with the whole soil volume and incubated for 60 days. After this period the soils were placed in the columns; the soil of the top ring was mixed with five poultry litter rates of $0,20,40,80$, and $160 \mathrm{tha}^{-1}$ (dry weight basis). Treatments consisted of a 4 × 5 x 2 factorial scheme corresponding to four MPAC levels, five poultry litter rates, two soils, with three replications, arranged in a completely randomized block design. Deionized water was percolated through the columns 10 times in 35 days to simulate about $1,200 \mathrm{~mm}$ rainfall. In the leachate of each column the inorganic $\mathrm{P}$ (reactive $\mathrm{P}, \mathrm{Pi}$ ) and organic $P$ forms (unreactive $P, P o$ ) were determined. At the end of the experiment, the columns were disassembled and $P$ was extracted with the extractants Mehlich-1 ( $\mathrm{HCl} 0.05 \mathrm{~mol} \mathrm{~L}^{-1}$ and $\mathrm{H}_{2} \mathrm{SO}_{4} 0.0125 \mathrm{~mol} \mathrm{~L}^{-1}$ ) and Olsen $\left(\mathrm{NaHCO}_{3} 0.5 \mathrm{~mol} \mathrm{~L}^{-1}, \mathrm{pH} \mathrm{8.5}\right)$ from the soil of each ring. The Pi and Po fractions were measured by the Olsen extractant. It was found that under higher poultry litter rates the losses of unreactive
\end{abstract}

\footnotetext{
(1) Part of the Master's Thesis of the first author, supported by FAPEMIG and CNPq. Submitted in June 2009, approved in June 2010.

(2) Graduate student in Soil and Plant Nutrition, Department of Soils, Universidade Federal de Viçosa - UFV. Av. PH Rolfs s/n, CEP 36570 000 Viçosa (MG). E-mails: fgebrim@yahoo.com.br; nandaschulthais@yahoo.com.br; leonardus_vergutz@yahoo.com.br; guilhermeluiz_ufv@yahoo.com.br

(3) Full Professor at the Department of Soils, UFV. E-mails: rfnovais@ufv.br; ivosilva@ufv.br

(4) Under-graduate student, Department of Soils, UFV. E-mails: lorena27_cp@yahoo.com.br; ffmoreira@yahoo.com.br
} 
$\mathrm{P}(\mathrm{Po})$ were 6.4 times higher than of reactive $\mathrm{P}(\mathrm{Pi})$. Both the previous $\mathrm{P}$ fertilization and increasing poultry litter rates caused a vertical movement of $P$ down the soil columns, as verified by $\mathrm{P}$ concentrations extracted by Mehlich-1 and $\mathrm{NaHCO}_{3}$ (Olsen). The environmental critical level (ECL), i.e., the $\mathrm{P}$ soil concentration above which $P$ leaching increases exponentially, was 100 and $150 \mathrm{mg} \mathrm{dm}^{-3}$ by Mehlich-1 and 40 and $60 \mathrm{mg} \mathrm{dm}^{-3}$ by Olsen, for the sandy loam and clay soils, respectively. In highly weathered soils, where residual $P$ is accumulated by successive crops, $P$ leaching through the profile can be significant, particularly when poultry litter is applied as fertilizer.

Index terms: eutrophication, environmental critical level, Mehlich-1, Olsen.

\title{
RESUMO: MOBILIDADE DE FORMAS INORGÂNICAS E ORGÂNICAS DE FÓSFORO SOB DIFERENTES DOSES DE ADUBAÇÃO FOSFATADA E CAMA DE AVIÁRIO EM SOLOS
}

\begin{abstract}
A eutroficação de aquíferos está fortemente ligada à mobilidade de P nos solos. Embora essa mobilidade tenha sido considerada, num passado mais distante, como inexpressiva, estudos mais recentes têm mostrado que o $P$, tanto na forma orgânica (Po) quanto na inorgânica (Pi), pode se perder por percolação e eluviação de partículas através do perfil de solos, particularmente naqueles menos intemperizados e, ou, arenosos com menor adsorção de $P$. $O$ objetivo deste trabalho foi verificar perdas por lixiviação e eluviação de formas de $P$ em colunas de solos, constituídas por cinco anéis de PVC sobrepostos, com $5 \mathrm{~cm}$ de diâmetro e $10 \mathrm{~cm}$ de altura cada, submetidas a fluxos de percolação de água. Foram utilizadas amostras de dois Latossolos Vermelho-Amarelos, texturas argilosa e média. Os solos receberam, previamente, quatro doses de $\mathrm{P}$ na forma de $\mathrm{KH}_{2} \mathrm{PO}_{4}$, correspondentes a 0; 12,5; 25 e $50 \%$ da capacidade máxima de adsorção de $P(C M A P)$, homogeneizadas com todo o volume de solo das colunas e deixados em incubação por 60 dias. No anel superior, aplicou-se, homogeneamente, cama de aviário nas doses equivalentes a 0, 20, 40, 80 e $160 \mathrm{th} \mathrm{h}^{-1}$, com base no peso do material seco. O experimento foi constituído pelo esquema fatorial: quatro níveis da CMAP, cinco doses de cama de aviário, dois solos, com três repetições dispostas em blocos casualizados. As colunas foram submetidas a 10 percolações com água deionizada, em duas aplicações semanais, durante 35 dias, de modo que se atingisse um volume aproximado de $1.200 \mathrm{~mm}$. Nos lixiviados de cada coluna, foram determinados: $P$ reativo (Pi) e P não reativo (Po). No final do experimento, o P no solo de cada anel foi extraído com Mehlich-1 e com $\mathrm{NaHCO}_{3}$ 0,5 mol L-1, $\mathrm{mH} 8,5$ (Olsen), sendo determinadas, para este último extrator, as formas Pi e Po. Com o aumento das doses aplicadas de cama de aviário, as perdas de P por lixiviação foram, em média, 6,4 vezes maiores na forma de $P$ não reativo $(P o)$ que no $P$-reativo (Pi). Tanto a fertilização mineral prévia com P quanto a aplicação de doses crescentes de cama de aviário causaram movimentação descendente de P nas colunas de solo, extraído tanto pelo Mehlich-1 quanto pelo $\mathrm{NaHCO}_{3}$ (Olsen). O nivel crítico ambiental (NCA), teor de P disponível no solo acima do qual a percolação de P-reativo aumenta exponencialmente, foi de 100 e $150 \mathrm{mg} \mathrm{dm}^{-3}$ para o Mehlich-1 e de 40 e $60 \mathrm{mg} \mathrm{dm}^{-3}$ para o Olsen, para os solos de textura média e argilosa, respectivamente. Em solos intemperizados, com acúmulo de P residual ao longo dos cultivos, as perdas de P por lixiviação no perfil podem ser significativas, de modo particular quando fertilizados com cama de aviário.
\end{abstract}

Termos de indexação: eutrofização, nível crítico ambiental, Mehlich-1, Olsen.

\section{INTRODUCTION}

Phosphorus is, in general, one of the most limiting elements for agricultural production in tropical soils. However, the presence of this nutrient can cause environmental problems, such as groundwater contamination. Given the high adsorption of $\mathrm{P}$ in most weathered soils, the leaching of this nutrient through such soils is hardly significant. In areas with less weathered soils, $\mathrm{P}$ mobility is verified in the soil profile, both in organic (Toor et al., 2004a,b) as well as inorganic forms (Turner \& Haygarth, 2000; Djodjic et al., 2004). Consequently, little weathered soils fertilized with $\mathrm{P}$ are more susceptible to $\mathrm{P}$ leaching 
(Robins et al., 2000; Sharpley \& Moyer, 2000, Whalen \& Chang, 2001, Daly et al., 2002; McDowel et al., 2002), particularly in terms of organic P (Po). In general, Po forms are more easily leached due to the low interaction with the soil (Ron Vaz et al., 1993; Eghball et al., 1996, Chardon et al., 1997). Soil solution concentrations about $0.277 \mathrm{mg} \mathrm{L}^{-1}$ Po have been found throughout the soil profile (Ron Vaz et al., 1993). This may cause environmental problems, although from the viewpoint of plant nutrition this level can be considered low (Turner \& Haygarth, 2000).

Several studies report the effect of organic fertilizers on P performance in soil. Hodgkinson et al. (2002) studied a clay soil in the region of Boxworth (Cambridgeshire, UK) and observed that the application of pig manure was able to increase the $\mathrm{P}$ concentration in drainage water when compared with chicken and cattle manure or sewage sludge. Robins et al. (2000) found that in calcareous soils, the organic and inorganic $\mathrm{P}$ forms in soil solution increased more after $\mathrm{P}$ application in the form of monocalcium phosphate than of waste. On the other hand, Heckrath et al. (1995) found that for the same P content, determined by the Olsen extractant, total $\mathrm{P}$ in drainage water from turf was lower after application of animal waste than of the inorganic form of the fertilizer. In this study, low $\mathrm{P}$ concentrations were stated in drainage water at levels of $60 \mathrm{mg} \mathrm{kg}^{-1} \mathrm{P}$ (Olsen), but when these levels exceeded $100 \mathrm{mg} \mathrm{kg}^{-1}, \mathrm{P}$ concentrations increased rapidly, increasing $\mathrm{P}$ soil leaching.

These $\mathrm{P}$ soil levels, at which the environmental problems related to water eutrophication become critical, can be considered environmental critical levels (ECL). Along this line of thought, McDowell \& Sharpley (2001) found that the ECLs would be 33 to $36 \mathrm{mg} \mathrm{kg}^{-1}$ by Olsen, and 185 to $190 \mathrm{mg} \mathrm{kg}^{-1}$ by Mehlich-3; Sharpley \& Moyer (2000) suggested that soluble $\mathrm{P}$ in water would be a good alternative to determine the ECL when animal manure is used.

In little weathered soils in temperate climate, the recommendation of organic sources is based on the $\mathrm{N}$ rate recommended to meet crop demands (Sharpley et al., 1993). Since crops generally have a P great demand, this nutrient is accumulated in the soil, which increases the possibility of $\mathrm{P}$ losses by leaching, eluviation and runoff (Sharpley et al., 1993, Whalen \& Chang, 2001). Along this line, Robinson \& Sharpley (1995) found that after the application of poultry litter, based on P crop requirements, the soil organic $\mathrm{P}$ forms are more stable, reducing the risk of environmental contamination.

In studies of Elliott et al. (2002), in P-deficient acid soils in the state of Florida (USA), it was observed that the lower the maximum $\mathrm{P}$ adsorption capacity (MPAC), the greater is the amount of $\mathrm{P}$ lost by leaching, mainly in the inorganic $\mathrm{P}$ form.

On the other hand, Field et al. (1985) found that increasing the poultry litter rate could not reduce the MPAC of the soil, but did reduce the bonding energy of $\mathrm{P}$ with the soil, causing leaching. Organic compounds in poultry litter, for example, have a relevant influence on $\mathrm{P}$ soil adsorption, since they are capable of coating the $\mathrm{Fe}$ and $\mathrm{Al}$ oxyhydroxides, reducing the soil adsorption capacity (Mazur et al., 1983, Beauchemin et al., 1996). However, there is little information on the movement of $\mathrm{P}$ forms in highly weathered soils.

The purpose of this study was to investigate the movement (leaching) of organic and inorganic $\mathrm{P}$ forms in samples of two Oxisols with different texture, treated with poultry litter, after previous $\mathrm{P}$ application in inorganic form. It is important to remember that the supply of organic P sources to soils causes increasing concerns about environmental problems such as ground water contamination, which are defused to a certain extent when inorganic $\mathrm{P}$ sources, as from mineral fertilizers, are used.

\section{MATERIAL AND METHODS}

PVC columns (height $50 \mathrm{~cm}$, diameter $5 \mathrm{~cm}$ ) were used, with two soil samples (Table 1) from two locations in the state of Minas Gerais: a clayey RedYellow Latosol from the region of Viçosa and a sandy loam texture Red-Yellow Latosol from the region of João Pinheiro. The experiment had a 4x5x2 factorial design, with four previous saturation levels of mineral soil $\mathrm{P}$, based on the maximum $\mathrm{P}$ adsorption capacity (MPAC), five fertilization levels with poultry litter and the two soils, with three replications, arranged in a completely randomized block design.

Samples of two soils were collected from subsurface horizons (B horizon), to reduce the interferences of organic matter. To the air-dried fine earth samples ( $2 \mathrm{~mm}$ sieve) $\mathrm{P}$ was added as monobasic potassium phosphate to reach the following MPAC values: 0 , $12.5,25$ and $50 \%$ of each soil, determined according to Olsen \& Watanabe (1957), with a shaking period of $16 \mathrm{~h}$ and the $\mathrm{P}$ source applied in solution. After 60 days of incubation, with soil moisture maintained at $90 \%$ field capacity and homogenized weekly, the soils were dried and packed in plastic bags.

Soil samples of each treatment were collected for $\mathrm{P}$ analysis by Mehlich-1 extractant $\left(\mathrm{HCl} 0.05 \mathrm{~mol} \mathrm{~L}^{-1}\right.$ and $\mathrm{H}_{2} \mathrm{SO}_{4} 0.0125 \mathrm{~mol} \mathrm{~L}^{-1}$ ); for the sandy loam texture soil, the values $0.15,12.7,35.9$ and $106.7 \mathrm{mg} \mathrm{dm}^{-3}$ of $\mathrm{P}$ were found and for the clay texture $0.01,33.6,85.8$ and $173.4 \mathrm{mg} \mathrm{dm}^{-3} \mathrm{P}$, respectively. The soils incubated with the P rates were placed in PVC columns composed of five rings (height $10 \mathrm{~cm}$ ), fixed to each other with scotch tape, and the inside coated with paraffin to avoid any preferential path of the water along the $\mathrm{PVC} /$ soil interface.

Poultry litter with wood shavings was applied to the top ring of each column at dry weight rates of 0 , 20, 40, 80 and 160 t ha $^{-1}$ (Table 2). So, different P rates were tested in soils with variable available-P status. 
Table 1. Chemical and physical properties of soil samples

\begin{tabular}{|c|c|c|}
\hline Property & $\begin{array}{c}\text { Clay } \\
\text { texture }\end{array}$ & $\begin{array}{c}\text { Sand loam } \\
\text { texture }\end{array}$ \\
\hline $\mathrm{pH}-\mathrm{H}_{2} \mathrm{O}(1: 2,5)$ & 4.80 & 5.40 \\
\hline $\mathrm{Al}^{3+}\left(\mathrm{cmol}_{\mathrm{c}} \mathrm{dm}^{-3}\right)^{(1)}$ & 1.10 & 0.45 \\
\hline $\mathrm{Ca}^{2+}\left(\mathrm{cmol}_{\mathrm{c}} \mathrm{dm}^{-3}\right)^{(1)}$ & 0.02 & 0.05 \\
\hline $\mathrm{Mg}^{2+}\left(\mathrm{cmol}_{\mathrm{c}} \mathrm{dm}^{-3}\right)^{(1)}$ & 0.01 & 0.01 \\
\hline $\mathrm{H}+\mathrm{Al}\left(\mathrm{cmol}_{\mathrm{c}} \mathrm{dm}^{-3}\right)^{(2)}$ & 6.70 & 3.20 \\
\hline $\mathrm{K}\left(\mathrm{mg} \mathrm{dm}^{-3}\right)^{(3)}$ & 4.10 & 9.90 \\
\hline $\mathrm{P}\left(\mathrm{mg} \mathrm{dm}^{-3}\right)^{(3)}$ & 0.30 & 0.30 \\
\hline Equilibrium P (mg L-1)(4) & 4.20 & 24.50 \\
\hline MPAC (mg g-1) $)^{(5)}$ & 2.48 & 0.76 \\
\hline Organic carbon $\left(\mathrm{g} \mathrm{kg}^{-1}\right)^{(6)}$ & 13.8 & 6.50 \\
\hline $\mathrm{SB}\left(\mathrm{cmol}_{\mathrm{c}} \mathrm{dm}^{-3}\right)$ & 0.04 & 0.08 \\
\hline $\operatorname{CEC~(t)~}\left(\mathrm{cmol}_{\mathrm{c}} \mathrm{dm}^{-3}\right)$ & 1.14 & 0.53 \\
\hline $\mathrm{CEC}_{\mathrm{pH}} 7.0(\mathrm{~T})\left(\mathrm{cmol}_{\mathrm{c}} \mathrm{dm}^{-3}\right)$ & 6.74 & 3.28 \\
\hline $\mathrm{m}(\%)$ & 96.50 & 84.90 \\
\hline V (\%) & 0.60 & 2.40 \\
\hline Coarse sand ( $\mathrm{g} \mathrm{k}$ & 130.0 & 260.0 \\
\hline Fine sand $\left(\mathrm{g} \mathrm{kg}^{-1}\right)^{(7)}$ & 70.0 & 500.0 \\
\hline Silt $\left(\mathrm{g} \mathrm{kg}^{-1}\right)^{(7)}$ & 20.0 & 30.0 \\
\hline Clay $\left(\mathrm{g} \mathrm{kg}^{-1}\right)^{(7)}$ & 780.0 & 210.0 \\
\hline Texture class & Very clayey & Franco-sandy-clay \\
\hline Field capacity $\left(\mathrm{kg} \mathrm{kg}^{-1}\right)^{(8)}$ & 0.35 & 0.10 \\
\hline \multicolumn{3}{|c|}{$\begin{array}{l}{ }^{(1)} \text { Extractant: } \mathrm{KCl} 1 \mathrm{~mol} \mathrm{~L}^{-1} \text { (Vettori, 1969). }{ }^{\left({ }^{(2)}\right.} \text { Extractant: } \\
\text { calcium acetate } 0.5 \mathrm{~mol} \mathrm{~L}^{-1}, \mathrm{pH} 7.0 \text { (Vettori, 1969). }{ }^{(3)} \text { Extractant: } \\
\text { Mehlich-1 (Defelipo \& Ribeiro, } 1997) .{ }^{(4)} \mathrm{P} \text { concentration of the } \\
\text { equilibrium solution, after shaking the soil with } 0.01 \mathrm{~mol} \mathrm{~L}^{-1} \\
\mathrm{CaCl}_{2} \text { for } 1 \mathrm{~h} \text {, containing } 60 \mathrm{mg} \mathrm{L}^{-1} \mathrm{P} \text { at a ratio of } 1: 10 \text { (Alvarez } \\
\text { et al., 2000). }{ }^{(5)} \text { Olsen \& Watanable (1957), modified by Alvarez } \\
\text { V. \& Fonseca (1990). }{ }^{(6)} \text { Method Walkley \& Black (Jackson, } \\
\text { 1958). (7) Pipette method (EMBRAPA, 1997). }{ }^{\left({ }^{8}\right)} \text { Method of } \\
\text { Richards (-30 KPa) (EMBRAPA, 1997). }\end{array}$} \\
\hline
\end{tabular}

Table 2. Total contents of macro and micronutrients and sodium in poultry litter with wood shavings

\begin{tabular}{lrllr}
\hline \multicolumn{2}{c}{ Macronutrient } & & \multicolumn{2}{c}{ Micronutrient } \\
\hline \multicolumn{2}{c}{$\mathrm{g} \mathrm{kg}^{-1}-$} & & \multicolumn{2}{c}{$\mathrm{mg} \mathrm{kg}^{-1}-$} \\
$\mathrm{N}$ & 30.9 & & $\mathrm{Zn}$ & 473 \\
$\mathrm{P}$ & $17.1^{*}$ & & $\mathrm{Fe}$ & 789 \\
$\mathrm{~K}$ & 24.4 & & $\mathrm{Mn}$ & 315 \\
$\mathrm{Ca}$ & 25.8 & & $\mathrm{C}$ & 41 \\
$\mathrm{Mg}$ & 5.7 & $\mathrm{~B}$ & 42 \\
$\mathrm{~S}$ & 14.0 & $\mathrm{Na}$ & 559
\end{tabular}

The total P content was determined by the method of Bowman (1989). Source: Souza (2004).

A PVC lid was placed at the bottom of each column, covered by a plastic screen on top of which a layer of glass wool and a layer of washed sand were placed to prevent soil loss from the column. A leachate collector tube was coupled to the base of each column, which linked the columns to the collector container. A system was installed on each column to control the water flow, as used for medical applications of drip-feeding, to forward the deionized water.

Deionized water was applied to the columns at a controlled flow of approximately $0.35 \mathrm{~mL} \mathrm{~min}^{-1}$ for the sandy and $0.42 \mathrm{~mL} \mathrm{~min}^{-1}$ for the clay soil texture. The water volume used in sandy loam and clay soil textures were, respectively, 250 and $300 \mathrm{~mL}$ of percolation, based on the pore volume of each soil. Ten percolations were performed, two per week, for 35 days, until an approximate value of the average annual rainfall in the region of Viçosa $(1,200 \mathrm{~mm}$, approximately) was reached. Throughout the experiment, the top of the columns was kept covered with plastic to prevent evaporation and capillary water rise.

From each of the ten percolations, the leachate was collected and the aliquots centrifuged at 2,606 g for $15 \mathrm{~min}$ and the supernatant filtered through millipore membrane, where the $\mathrm{P}$ forms were fractionated in reactive $(\mathrm{Pi})$ and non-reactive $(\mathrm{Po})$ forms. The reactive $\mathrm{P}(\mathrm{Pi})$ was obtained by direct determination (without additional treatment) of $\mathrm{P}$ in solution in an aliquot of the leachate. The inorganic $\mathrm{P}$ forms in solution, which form the phosphomolybdic complex (Novais \& Smyth, 1999), were determined by the colorimetric method according to Murphy \& Riley (1962) Given the very low P concentrations in solution, a large cell $(70 \mathrm{~mm})$ was used in a number of determinations, increasing the sensitivity of the method (concentrations equal to or higher than $\left.0.025 \mathrm{mg} \mathrm{L}^{-1}\right)$. In another aliquot, the total $\mathrm{P}(\mathrm{Pt})$ was determined after digestion with potassium peroxidisulphate $\left(\mathrm{K}_{2} \mathrm{~S}_{2} \mathrm{O}_{8}\right)$ in alkaline medium (Cabrera \& Beare, 1993), as modified by Doyle et al. (2004). The non-reactive $\mathrm{P}(\mathrm{Po})$ was estimated by the difference between $\mathrm{Pt}$ and $\mathrm{Pi}$.

At the end of the experiment, the columns were dismantled and the soil from the different rings separated, air-dried, crumbled, sieved (2 mm mesh), and then the $\mathrm{P}$ levels were determined, extracted by Mehlich-1 and by $\mathrm{NaHCO}_{3} 0.5 \mathrm{~mol} \mathrm{~L}^{-1}$, at $\mathrm{pH} 8.5$ (Olsen).

For the Mehlich-1 extractions, $100 \mathrm{~mL}$ of extractant was added to every $10 \mathrm{~cm}^{3}$ of soil, shaken for 5 min and after $16 \mathrm{~h}$ of rest an aliquot was pipetted for $\mathrm{P}$ analysis and determined colorimetrically, according to EMBRAPA (1997).

For $\mathrm{NaHCO}_{3}$ extraction, $25 \mathrm{~mL}$ of extractant was used per $2.5 \mathrm{~cm}^{3}$ soil, packed in $50 \mathrm{~mL}$ Falcon centrifuge tubes, shaken horizontally at $150 \mathrm{RPM}$, at $4{ }^{\circ} \mathrm{C}$ for $1 \mathrm{~h}$; then the tubes were centrifuged at $2,606 \mathrm{~g}$ for $10 \mathrm{~min}$, at $4{ }^{\circ} \mathrm{C}$, and then an aliquot was taken to determine Pi as described by Murphy \& Riley (1962), by the so-called $\mathrm{Pi}-\mathrm{NaHCO}_{3}$. A second aliquot was subjected to nitro-perchloric digestion, at a ratio of $4: 1, \mathrm{v} / \mathrm{v}$-(nitric: perchloric acid) for determination of total $\mathrm{P}(\mathrm{Pt})$. The $\mathrm{Po}-\mathrm{NaHCO}_{3}$ was computed by the difference: $\mathrm{Pt}-\mathrm{Pi}$.

The $\mathrm{pH}$ values of all extracts were adjusted, taking as reference the indicator p-nitrophenol, to determine the P levels, except for the Mehlich-1 extractant, where the $\mathrm{pH}$ was already within the range recommended for the determination ( $\mathrm{pH}$ about 4.5-5.5) 
The statistical analysis was performed using software sigma-plot 8.0, Statistica 6.0 and SAEG 9.0, including ANOVA and regression settings, where appropriate. Subsequently, the significance of the adjusted regression coefficients was t- tested.

\section{RESULTS AND DISCUSSION}

\section{Reactive phosphorus (Pi) and non-reactive (Po) in the leachate}

The $\mathrm{P}$ loss in solution leached from columns occurred both in the form of reactive $\mathrm{P}(\mathrm{Pi})$ (Figure 1) as in the form of non-reactive $\mathrm{P}(\mathrm{Po})$ (Figure 2) in both soils. The non-application of poultry litter on soil not prefertilized with phosphate (0 \% MPAC) promoted

$$
\begin{aligned}
& \hat{y}_{(1)}=0.0025^{n s}+0.0022^{* *} x \mathrm{R}^{2}=0.93 \\
& \hat{y}_{(2)}=0.0853^{*}+0.0010^{*} x \mathrm{R}^{2}=0.99 \\
& \hat{\boldsymbol{y}}_{(3)}=\mathbf{0 . 4 3 4 8}^{*}-0.0078^{o} x+0.0001^{o} x^{2}-4.9193 e^{-7^{o}} x^{3} \mathrm{R}^{2}=0.99 \\
& \hat{y}_{(4)}=3.9857^{*}+0.0512^{o} x-0.0015^{*} x^{2}+7.059 e^{-6^{*}} x^{3} \quad \mathrm{R}^{2}=0.99
\end{aligned}
$$

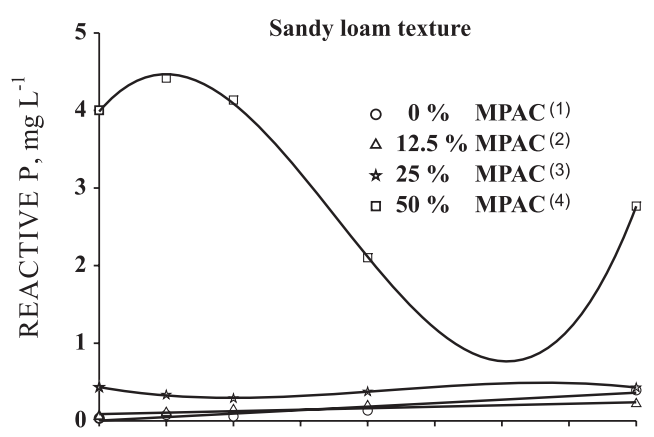

$$
\begin{aligned}
& \hat{y}_{(1)}=0.0373^{n s}+0.0005^{o} \times R^{2}=0.68 \\
& \hat{y}_{(2)}=0.0406^{\circ}+0.0008^{*} x \quad R^{2}=0.87 \\
& \hat{y}_{(3)}=0.1320^{* *}+0.0012^{*} x R^{2}=0.86 \\
& \hat{y}_{(4)}=4.1599^{n s}+0.0228^{n s} x-0.0007^{n s} x^{2}+3.17 e^{-6^{o o}} x^{3} R^{2}=0.65
\end{aligned}
$$

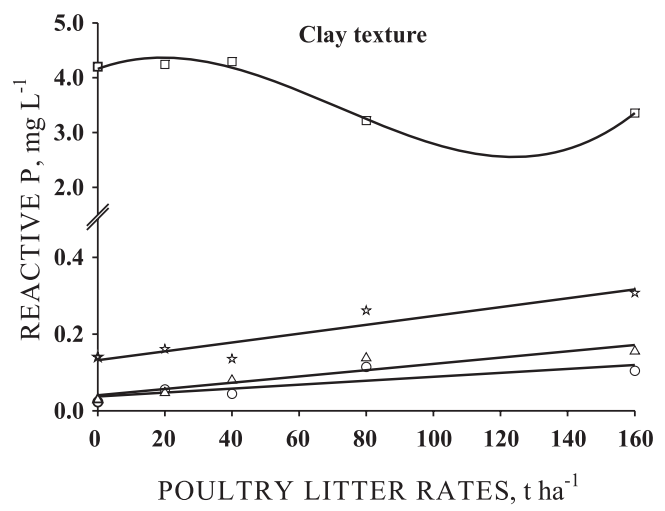

Figure 1. Concentrations of reactive $\mathrm{P}(\mathrm{Pi})$ in leachate collected from two Latosols of sandy loam and clay texture, prefertilized with increasing rates of mineral $P$, as related with the poultry litter rates applied in the top ring. ${ }^{\mathrm{ns}}$, ${ }^{\text {oo }},{ }^{\circ}, *, * *$ : not significant and significant at 15,10 , 5 and $1 \%$, respectively.

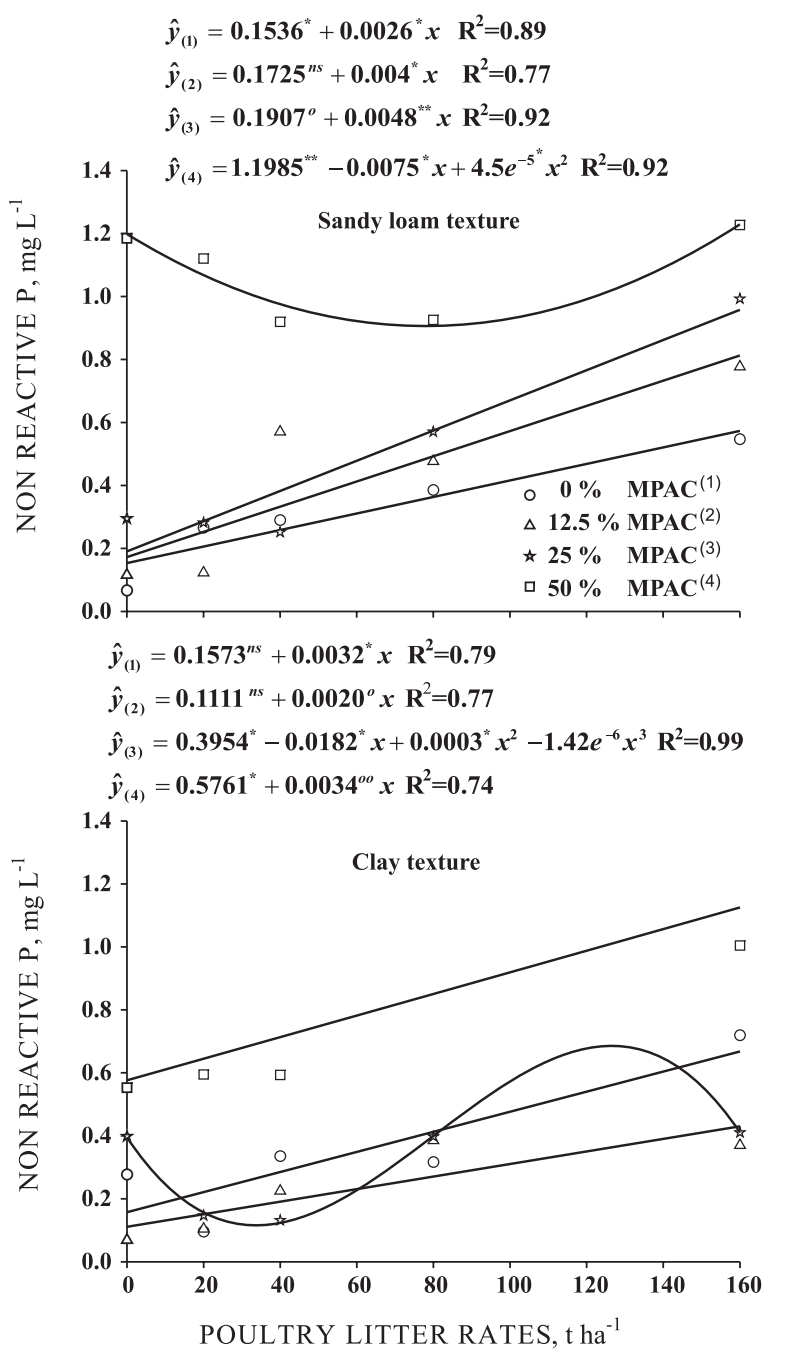

Figure 2. Concentrations of non-reactive $\mathbf{P}(\mathrm{Po})$ in leachate from two Latosols of sandy loam and clay texture, prefertilized with increasing rates of mineral $P$, as related to poultry litter rates applied in the top ring. ${ }^{\text {ns }},{ }^{\text {oo }},{ }^{\circ}, *, * *$ not significant and significant at $15,10,5$ and $1 \%$, respectively.

low $\mathrm{P}$ concentrations in the leachate, near zero, with predominance of non-reactive over reactive $P$.

Despite the different soil adsorption capacity (Table 1), the similarity between $\mathrm{P}$ concentrations of reactive and non-reactive $\mathrm{P}$ was evident (Figures 1 and 2). This was expected, since the previous $\mathrm{P}$ fertilization was based on the MPAC of each soil, with application of different $P$ rates to the soils up to the MPAC saturation level. Possible differences in results as a consequence of different clay contents between soils were therefore compensated.

The increase in the rate of poultry litter applied to soil under original conditions (0\% MPAC) caused higher losses of non-reactive ( $\mathrm{Po}$ ) than of reactive $\mathrm{P}$ (Pi) in the clay soil. While the tangential to Po in $\mathrm{mg} \mathrm{L}^{-1} \mathrm{P} / \mathrm{t}$ ha-1 of poultry litter was 0.0032 (Eq. 1 Figure 2), the equivalent tangent for $\mathrm{Pi}$ in the same 
soil was 0.0005 (Eq. 1 - Figure 1), indicating higher Po losses, 6.4 times greater than of $\mathrm{Pi}$, in these conditions. This greater Po percolation suggests a lower interaction of this $\mathrm{P}$ form with the soil than of the inorganic form $\mathrm{Pi}$, as already shown in several studies (Toor et al., 2004a, b, Anderson \& Magdoff, 2005). The same comparison for the sandy loam texture soil indicates similar losses for $\mathrm{Po}$ and $\mathrm{Pi}$, with tangents of 0.0022 and 0.0026 , respectively.

As the most predominant model, increasing losses of the two $\mathrm{P}$ forms in leachate were observed with increasing $P$ poultry litter rates applied to both soils, with exception of $\mathrm{Pi}$ at the highest prefertilization rate (50 \% MPAC). The Po content in sandy loam texture soil, previously fertilized with phosphorus of $50 \%$ MPAC, also tended to increase with the increasing poultry litter rate.

The lower Pi concentrations observed with increasing $P$ poultry litter rates, according to a cubic model (Figure 1) in both soils, suggest a greater clay dispersion that occurred with increasing poultry litter rates to an intermediate point between the two rates (121.8 $\mathrm{t} \mathrm{ha}^{-1}$ for sandy loam and $128.5 \mathrm{t} \mathrm{ha}^{-1}$ for clay soil texture). The increased Pi concentration after the minimum point in the curves suggests a compensation of the negative effect of the lower soil hydraulic conductivity in the column due to the higher total $\mathrm{P}$ rate added in the form of poultry litter.

The attempt to perform one more percolation - the eleventh - was unsuccessful because in several columns, most evidently in those treated with higher poultry litter rates, there was no more leachate and the water was accumulated on top of the columns without the expected infiltration.

According to Benites \& Mendonça (1998), the application of high rates of organic compounds to soils, as of animal manure, leads to a strong prevalence of negative charges, so aggregation is reduced. It is noteworthy that not only organic compounds are present in poultry litter, as a soil disintegrating agent, but also high levels of $\mathrm{Na}$, a dispersant agent found in animal feed, which is confirmed by the Na contents measured in poultry litter used here (Table 2).

\section{Soil phosphorus in each ring after percolations \\ Phosphorus extracted by Mehlich-1}

With the previous fertilization of soil samples with mineral $\mathrm{P}$ source, simulating years of nutrient addition in the field, $\mathrm{P}$ levels by Mehlich-1 (Pm) in depth increased significantly, especially in clay soil texture (Figure 3). It was also observed that with the application of poultry litter, Pm levels increased in the first layer (first ring, $0-10 \mathrm{~cm}$ ) and in depth, although in this case less significantly. These results indicate that the use of poultry litter in soils pretreated with phosphate fertilizer, resulting in a high soil $\mathrm{P}$ status may induce $\mathrm{P}$ transport to deeper profile layers. They further indicate $\mathrm{P}$ losses in this form $\mathrm{P}$
$(\mathrm{Pm})$ before the MPAC soil was affected as a result of the application of increasing poultry litter rates (Figure 3).

\section{Inorganic and organic phosphorus extracted by $\mathrm{NaHCO}_{3}$}

Opposite to what occurs with the acid extractants such as Mehlich-1 (pH 1.2) (Novais \& Smyth, 1999) the extractant $\mathrm{NaHCO}_{3}(\mathrm{pH}$ 8.5) has a strong extraction power of organic $\mathrm{P}(\mathrm{Po})$ from the soil (Hedley et al., 1982), which allows a more critical examination of this P form. Similarly as already observed for Mehlich-1, in Pi extracted by $\mathrm{NaHCO}_{3}\left(\mathrm{Pi}-\mathrm{NaHCO}_{3}\right)$ the prefertilization of soil samples with the mineral source increased the $\mathrm{Pi}-\mathrm{NaHCO}_{3}$ levels significantly, mainly in clay soil (Figure 4). The application of poultry litter also caused increases in $\mathrm{Pi}-\mathrm{NaHCO}_{3}$ levels in depth; increases were more pronounced according to increases of the previous $\mathrm{P}$ soil saturation levels, giving them the status of more fertile soils for this nutrient.

Under the present conditions in the soil columns high mobility of $\mathrm{Pi}-\mathrm{NaHCO}_{3}$ and $\mathrm{Po}-\mathrm{NaHCO}_{3}$ was observed in the deeper soil columns (Figures 4 and

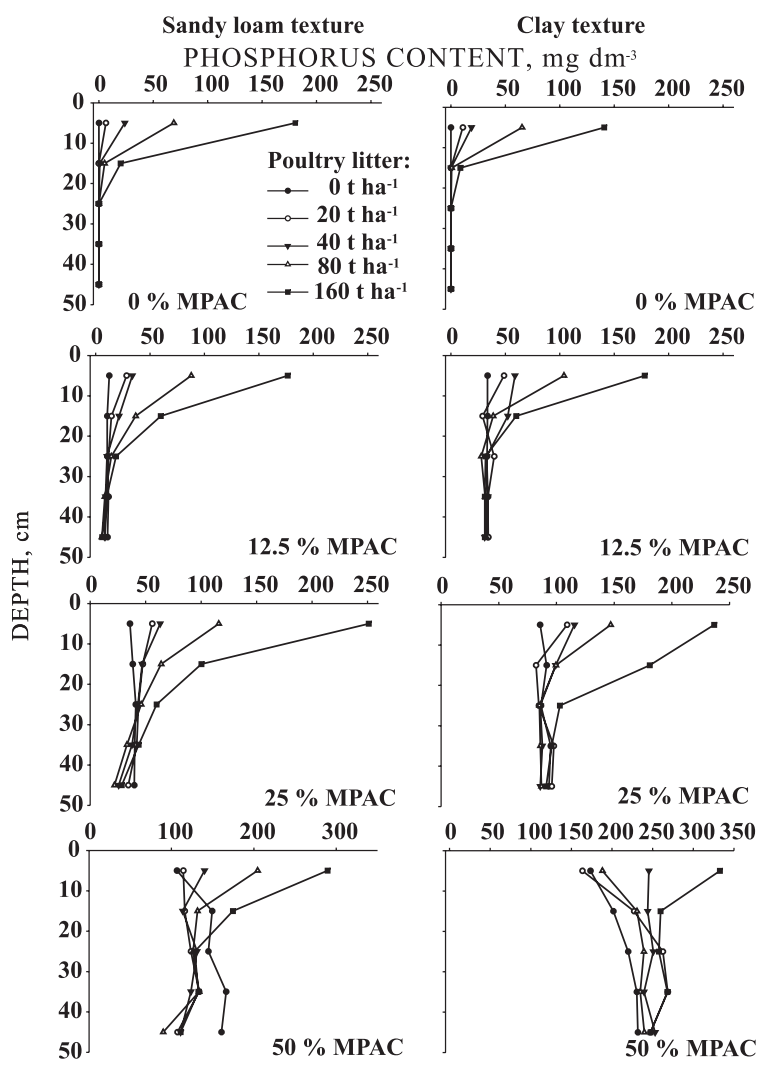

Figure 3. Phosphorus contents by Mehlich-1 (Pm) in samples of two Latosols with sandy loam and clay texture, prefertilized with increasing mineral $P$ rates corresponding to the percentages of Maximum Phosphorus Adsorption Capacity (MPAC), as related to the poultry litter rates applied in the top ring. 


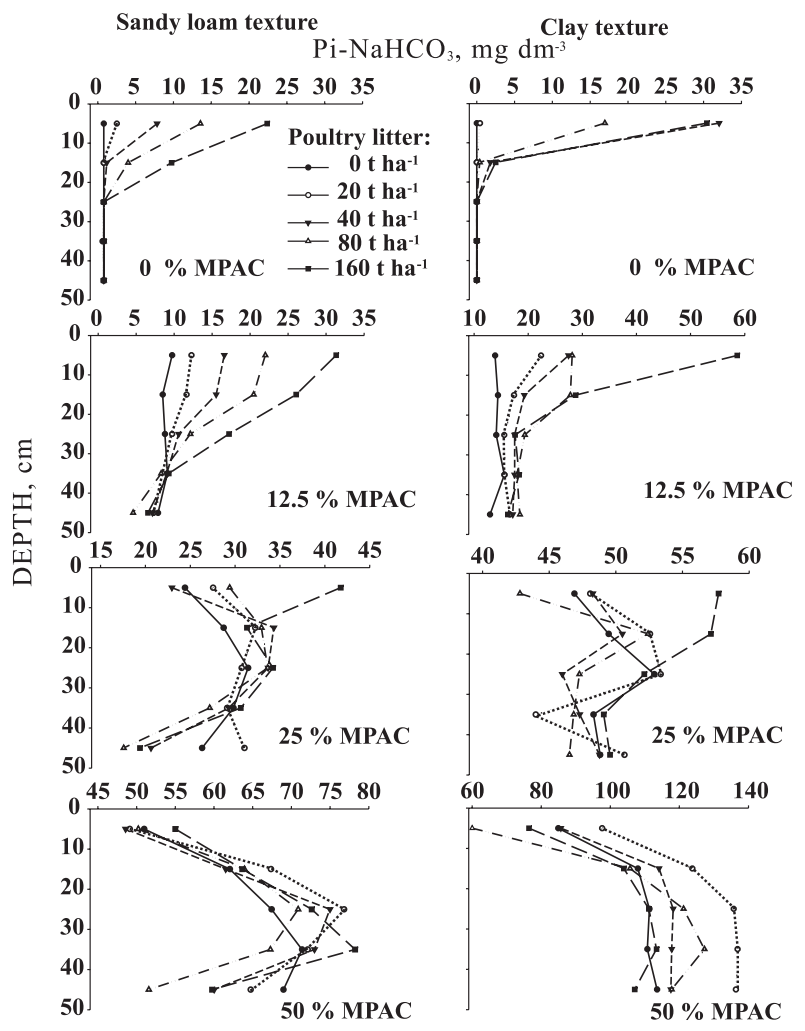

Figure 4. Inorganic phosphorus contents (Pi) extracted by $\mathrm{NaHCO}_{3}\left(\mathrm{Pi}-\mathrm{NaHCO}_{3}\right)$ in samples of two Latosols with sandy loam and clay texture, prefertilized with increasing mineral $P$ rates as related to the poultry litter rates applied in the top ring.

5), suggesting the potential eutrophication of water bodies, as widely reported in the literature (Sharpley \& Moyer, 2000, McDowell et al. , 2002).

The mineral phosphate prefertilization of samples probably increased the competition for adsorption sites of soil $\mathrm{P}$, tending to saturate them and making them less restrictive to $\mathrm{P}$ losses by percolation/leaching. This was observed more intensely in the samples phosphated with $50 \%$ of MPAC, regardless of the amount of poultry litter applied, mainly in the clay soil (Figures 4 and 5). It is emphasized that for the same \% of MPAC, the $\mathrm{P}$ rate applied in the clay soil was 3.16 times higher than in sandy soil (Table 1).

Environmental critical level (ECL) of phosphorus extracted by Mehlich-1 and $\mathrm{NaHCO}_{3}$

The reactive $\mathrm{P}(\mathrm{Pi})$ concentrations remained low until the status of available $\mathrm{P}$ in the soil of the first ring reached 100 and $150 \mathrm{mg} \mathrm{dm}^{-3}$ of Mehlich-1 P $(\mathrm{Pm})$, approximately, in the soils of sandy loam and clay texture, respectively. From these levels, the increments in concentrations became more than proportional to the increase in the Pm levels, suggesting that the adsorption capacity of soil $\mathrm{P}$ was then reduced drastically for both soils (Figure 6). These Pm levels may indicate the "environmental critical levels" (ECL), as suggested by some authors (Maguire \& Sims, 2002, Sharpley et al., 2004). Moreover, the leaching of non-reactive $\mathrm{P}(\mathrm{Po})$ increased linearly with increasing Pm levels, which suggests a lower affinity of this $\mathrm{P}$ form with the soil, even when soil $\mathrm{P}$ saturation is low.

The results indicate that organic residues, e.g., poultry litter, reduce the MPAC and/or adsorption energy of $\mathrm{P}$ forms ( $\mathrm{Pi}$ and $\mathrm{Po}$ ) by the soil.

The reactive $\mathrm{P}$ concentrations in leachate also remained low until a status of available soil $\mathrm{P}$ of 40 and $60 \mathrm{mg} \mathrm{dm}^{-3} \mathrm{Pi}-\mathrm{NaHCO}_{3}$ in sandy loam and clay soil texture, respectively, was reached in the first ring. From this point on, $\mathrm{P}$ losses from the columns increased exponentially (Figure 7) in a model similar to that observed for Pm (Figure 6).

These Pi-NaHCO $\mathrm{HC}_{3}$ levels also indicated the ECLs for this extractant, which are close to those suggested

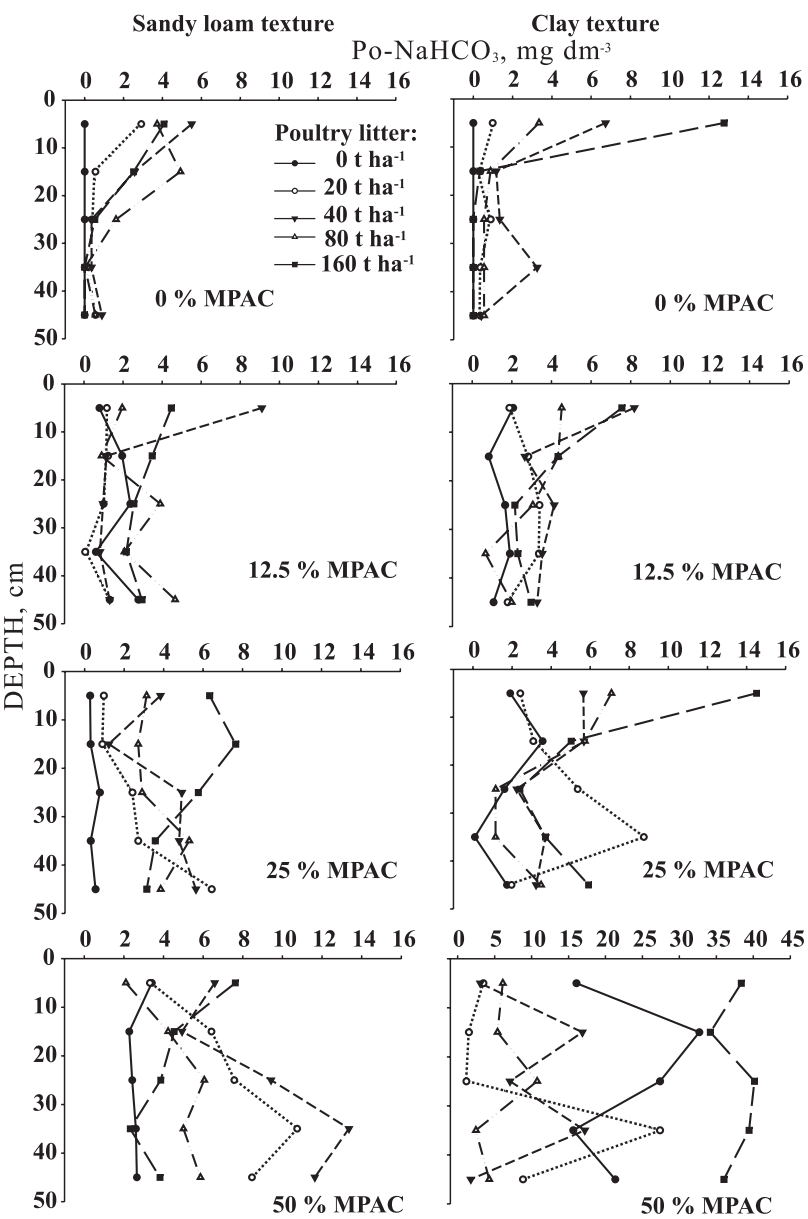

Figure 5. Organic phosphorus contents (Po) extracted by $\mathrm{NaHCO}_{3}\left(\mathrm{Po}-\mathrm{NaHCO}_{3}\right)$ from samples of two Latosols with sandy loam und clay texture, prefertilized with increasing mineral $P$ rates as related to the poultry litter rates applied in the top ring. 
in the literature. McDowell \& Sharpley (2001) found ECLs of around 33 to $36 \mathrm{mg} \mathrm{kg}^{-1} \mathrm{P}$ for Olsen. These values are close to the $40 \mathrm{mg} \mathrm{dm}^{-3} \mathrm{P}$ for sandy loam soil texture observed here. McDowell \& Sharpley (2001) found ECLs of 185 to $190 \mathrm{mg} \mathrm{kg}^{-1} \mathrm{P}$ by the Mehlich-3 extractant, close to the ECL values found here (Figure 6) by Mehlich-1 (150 $\left.\mathrm{mg} \mathrm{dm}^{-3}\right)$.

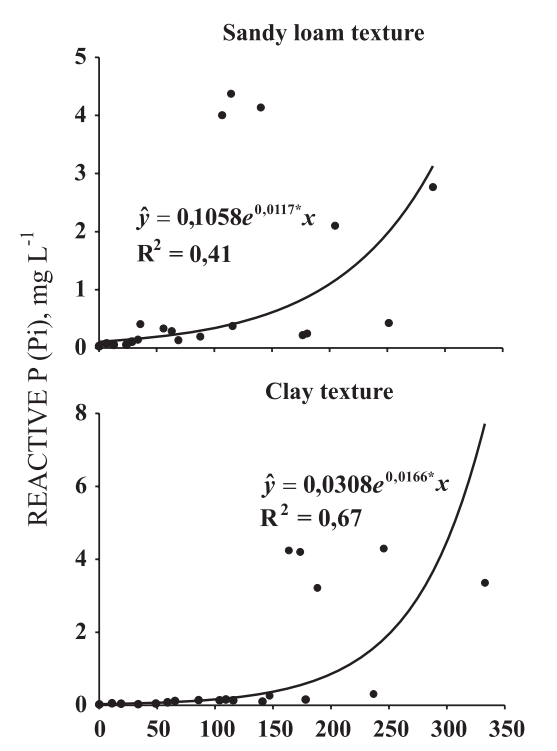

Similarly as for Mehlich-1 (Figure 6) there was a linear increase of non-reactive $\mathrm{P}$ due to the increased $\mathrm{Pi}-\mathrm{NaHCO}_{3}$ levels in the soil in the first ring (Figure 7). The losses of non-reactive $\mathrm{P}$ per unit of $\mathrm{P}$ $\mathrm{NaHCO}_{3}$ were higher for sandy loam $\left(0.0202 \mathrm{mg} \mathrm{L}^{-1 /}\right.$ $\left.\mathrm{mg} \mathrm{dm}^{-3}\right)$ than for clay texture soil $\left(0.0056 \mathrm{mg} \mathrm{L}^{-1 /}\right.$ $\mathrm{mg} \mathrm{dm}^{-3}$ ) (Figure 7).

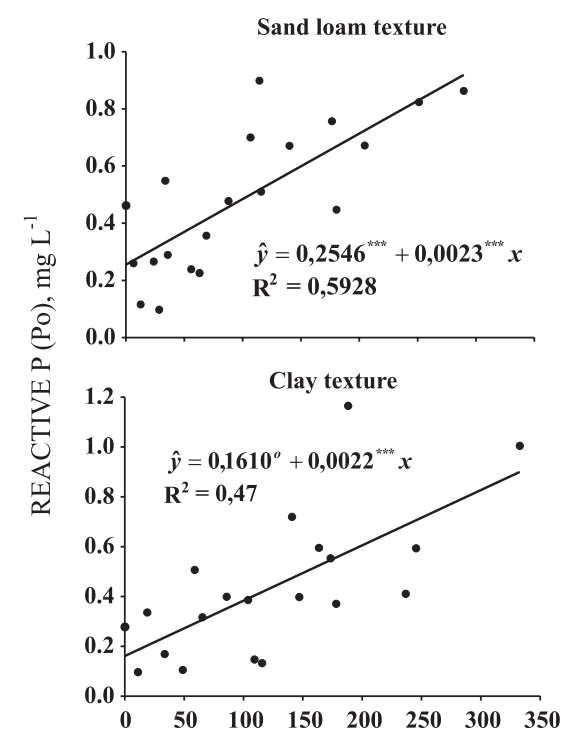

Figure 6. Variation in $\mathrm{P}$ reactive $(\mathrm{Pi})$ and $\mathrm{P}$ non-reactive $(\mathrm{Po})$ contents in the leachates according to the $\mathrm{P}$ contents extracted by Mehlich-1 in the top ring $(0-10 \mathrm{~cm})$ in two soil samples of Latosols of sandy loam and clay texture, prefertilized with increasing mineral $P$ rates corresponding to the percentages of Maximum Phosphorus Adsorption Capacity (MPAC), as influenced by the application of increasing poultry litter rates. *, ****: significant at 5 and $0.1 \%$, respectively.

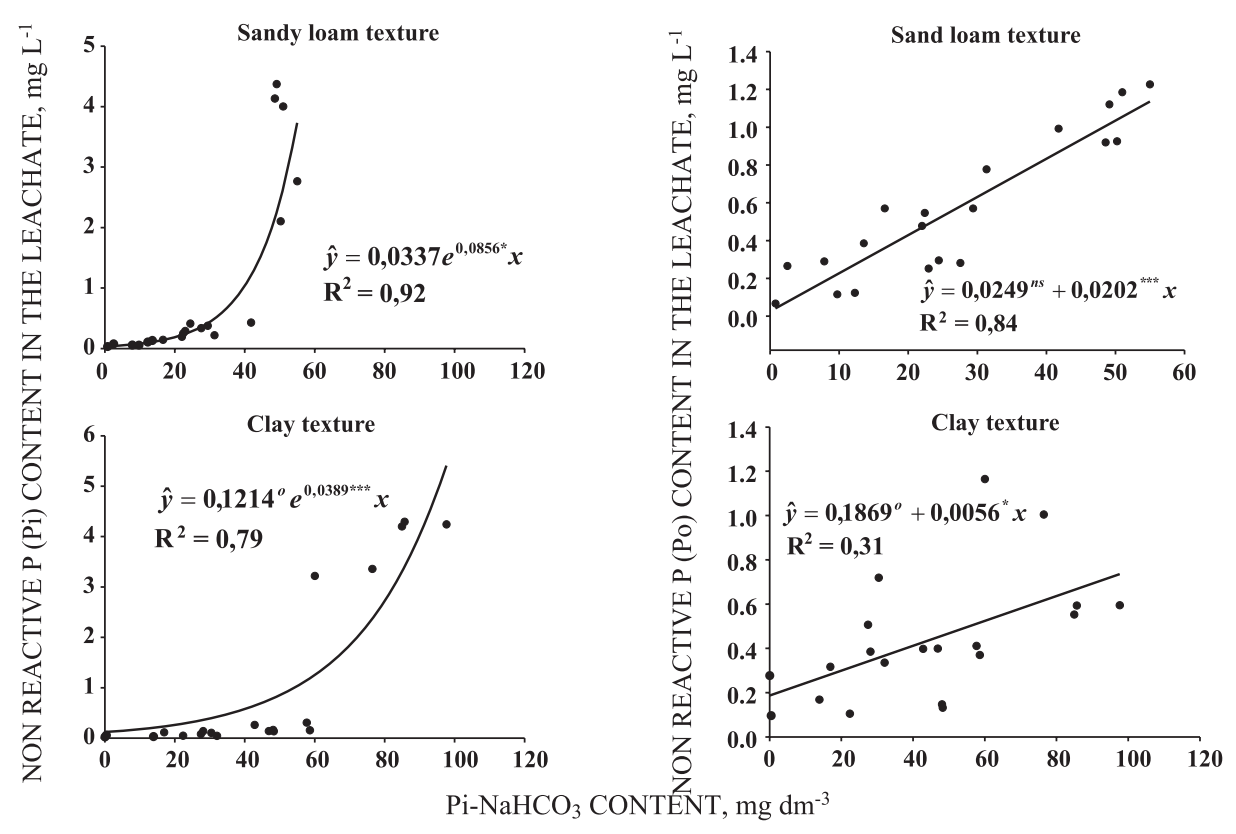

Figure 7. Variation in $\mathrm{P}$ reactive $(\mathrm{Pi})$ and $\mathrm{P}$ non-reactive $(\mathrm{Po})$ contents in the leachates according to the contents of $\mathrm{Pi}-\mathrm{NaHCO}_{3}$ in the first ring $(0-10 \mathrm{~cm})$ in samples of two Latosols with sandy loam and clay texture, with increasing mineral $P$ rates corresponding to the percentages of Maximum Phosphorus Adsorption Capacity (MPAC), under the influence of increasing poultry litter rates. ${ }^{\text {ns }},{ }^{\circ}, *, * * * *$ not significant and significant at 10,5 , and $0.1 \%$, respectively. 


\section{Environmental Critical Rate (ECR) of phosphorus}

The change of the values of reactive $\mathrm{P}(\mathrm{Pi})$ caused by total $\mathrm{P}$ rates applied in the first ring $(0-10 \mathrm{~cm})$ was curvilinear but linear in the case of non-reactive $\mathrm{P}(\mathrm{Po})$. The values were computed by the sum of the rates applied as soluble phosphate prefertilizer and as poultry litter (Figure 8), assuming that $61 \%$ of the total $\mathrm{P}$ is in inorganic form, as previously determined by Souza (2004) in a sample of the same poultry litter. From this relationship it was possible to estimate a "environmental critical rate" (ECR), or rate above which the environmental problems caused by $\mathrm{P}$ percolation in the profile, reaching groundwater and surface waters, could become a concern (Figure 8).

The increase of reactive $\mathrm{P}$ loss $(\mathrm{Pi})$ from sandy loam texture soil begins at $\mathrm{P}$ rates two to three times lower than for clay soil, indicating differences in the MPAC between the two soils. On the other hand, an increase of the total $\mathrm{P}$ rates leads to linear increases in the percolation of non-reactive $\mathrm{P}(\mathrm{Po})$, even in conditions
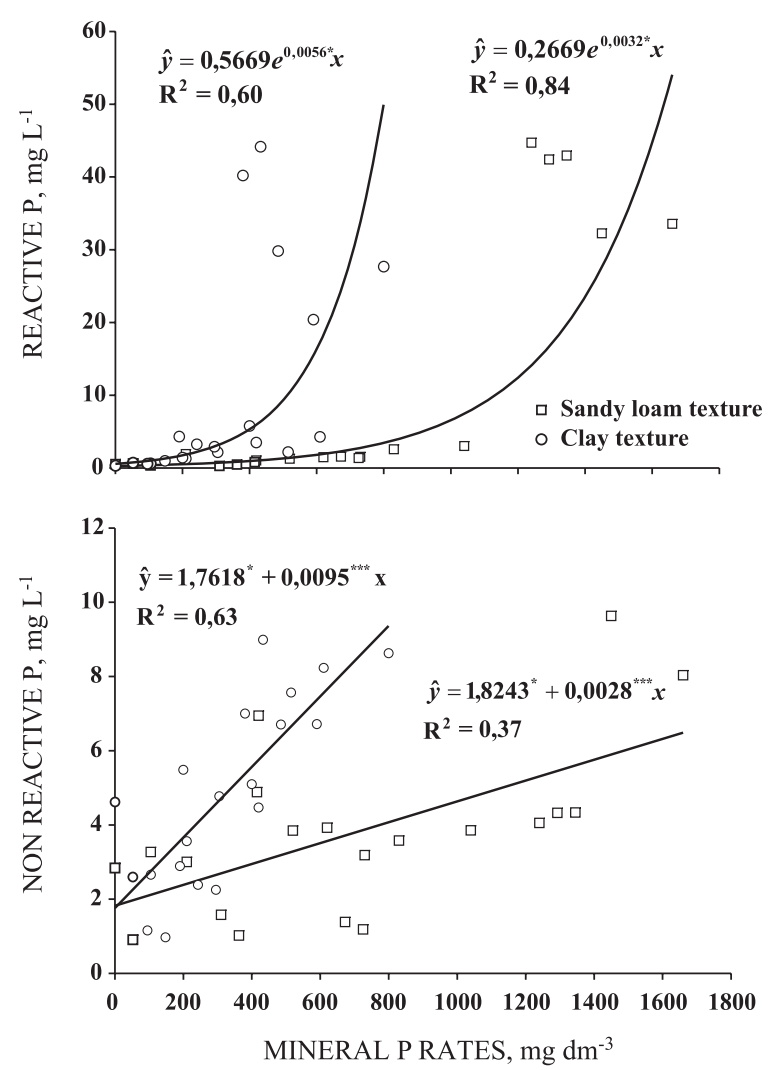

Figure 8. Concentration of reactive $\mathrm{P}(\mathrm{Pi})$ and nonreactive $\mathrm{P}(\mathrm{Po})$ in the leachates according to the rate of total mineral $P$ applied in the first ring $(0-10 \mathrm{~cm})$, calculated by the sum of mineral prefertilization and poultry litter application, presuming that $61 \%$ of the total of this material is in the inorganic form, in samples of two Latosols with sandy loam and clay texture. *, ****: significant at 5 and $0.1 \%$, respectively. of no previous phosphating ( $0 \% \mathrm{MPAC})$. However, at higher rates, losses of reactive $\mathrm{P}(\mathrm{Pi})$ are more than proportional. While there are practically no losses of reactive $\mathrm{P}$ from the soil columns at the lowest preapplied mineral phosphate rates, the loss of nonreactive $\mathrm{P}(\mathrm{Po})$ is between $1.76 \mathrm{mg} \mathrm{L}^{-1}$ for clay soil and $1.82 \mathrm{mg} \mathrm{L}^{-1}$ for sandy loam texture soil (Figure 8). By the model of alteration of reactive $\mathrm{P}(\mathrm{Pi})$ as variable of the mineral $\mathrm{P}$ rates applied, it can be estimated, approximately, that reactive $\mathrm{P}$ concentrations increased exponentially at rates above 300 to $350 \mathrm{mg} \mathrm{dm}^{-3}$ mineral $\mathrm{P}$ in sandy loam and above 900 to $1,050 \mathrm{mg} \mathrm{dm}^{-3}$ in clay soil texture.

The lower angular coefficient for losses of nonreactive $\mathrm{P}$ as variable of the $\mathrm{P}$ rates $\left(0.0028 \mathrm{mg} \mathrm{L}^{-1 /}\right.$ $\mathrm{mg} \mathrm{dm}{ }^{-3}$ ) indicates that the clay texture soil is less susceptible to $\mathrm{P}$ loss than the sandy loam texture soil (0.0095 $\mathrm{mg} \mathrm{L}^{-1} / \mathrm{mg} \mathrm{dm}^{-3}$ ) (Figure 8).

\section{CONCLUSIONS}

1. In natural conditions of low soil $\mathrm{P}$ availability, the loss of soil $\mathrm{P}$ by percolation of non-reactive $\mathrm{P}(\mathrm{Po})$ was higher than of reactive $\mathrm{P}(\mathrm{Pi})$.

2. The downward movement of $\mathrm{P}$ extracted by Mehlich-1 in the soil column increased greatly with higher rates of mineral $P$ prefertilization and also with the amount of poultry litter.

3. The use of poultry litter in soil pre-treated with phosphate fertilizer, resulting in a high soil $\mathrm{P}$ status, induced increasing percolation of $\mathrm{P}$, mainly in the nonreactive form $(\mathrm{Po})$.

4. The environmental critical levels (ECL) for the P-extractant Mehlich-1 were approximately 100 and $150 \mathrm{mg} \mathrm{dm}^{-3}$ and 40 and $60 \mathrm{mg} \mathrm{dm}^{-3}$ for the extractant $\mathrm{NaHCO}_{3}(\mathrm{Olsen})$ for sandy loam and clay soil texture, respectively.

\section{LITERATURE CITED}

ALVAREZ V., V.H. \& FONSECA, D.M. Definição de rates de fósforo para determinação da capacidade máxima de adsorção de fosfatos e para ensaios em casa de vegetação. R. Bras. Ci. Solo, 14:49-55, 1990.

ALVAREZ V., V.H.; NOVAIS, R.F.; DIAS, L.E. \& OLIVEIRA, J.A. Determinação e uso do fósforo remanescente. B. Inf. SBCS, 25:27-34, 2000.

ANDERSON, B.H. \& MAGDOFF, F.R. Relative movement and soil fixation of soluble organic and inorganic phosphorus. J. Environ. Qual., 34:2228-2233, 2005.

BEAUCHEMIN, S.; SIMARD, R.R. \& CLUIS, D. Phosphorus sorption-desorption kinetics of soil under contrasting land uses. J. Environ. Qual., 25:1317-1325, 1996. 
BENITES, V.M. \& MENDONÇA E.S. Propriedades eletroquímicas de um solo eletropositivo influenciadas pela adição de diferentes fontes de matéria orgânica. $R$. Bras. Ci. Solo, 22:215-221, 1998

BOWMAN, R.A. A sequential extraction procedure with concentrated sulfuric acid and dilute base for soil organic phosphorus. Soil Sci. Soc. Am. J., 53:326-366, 1989.

CABRERA, M.L. \& BEARE, M.H. Alkaline persulfate oxidation for determining total nitrogen in microbial biomass extracts. Soil Sci. Soc. Am. J., 37:1007-1012, 1993.

CHARDON, W.J.; OENEMA, O.; CASTILHO, R.; VRIESEMA, R.; JAPENGA, J. \& BLASUV, D. Organic phosphorus in solutions and leachates from soils treated with animal slurries. J. Environ. Qual., 26:372-378, 1997.

DALY, K.; MiLls, P.; COUTER, B. \& McGANiGLE, M. Modeling phosphorus concentrations in Irish rivers using land use, soil type, and soil phosphorus data. J. Environ. Qual., 31:590-599, 2002.

DEFELIPO, B.V. \& RIBEIRO, A.C. Análise química do solo (metodologia). 2.ed. Viçosa, MG, Universidade Federal de Viçosa, 1997. 26p. (Boletim de Extensão, 29)

DJODJIC, F.; BÖRLING, K. \& BERGSTRÖM, L. Phosphorus leaching in relation to soil type and soil phosphorus content. J. Environ. Qual., 33:678-682, 2004.

DOYLE, A.; WEINTRAUB, M.N. \& SCHIMEL, J.P. Persulfate digestion and simultaneous colorimetric analysis of carbon and nitrogen in soil extracts. Soil Sci. Soc. Am. J., 68:669676,2004

EGHBALL, B.; BINFORD G.D. \& BALTENSPERGER, D.D. Phosphorus movement and adsorption in a soil receiving long-term manure and fertilizer application. J. Environ. Qual., 25:1339-1343, 1996.

ELLIOTT, H.A.; O'CONNOR, G.A. \& BRINTON, S Phosphorus leaching from biosolids-amended sandy soils. J. Environ. Qual., 31:681-689, 2002.

EMPRESA BRASILEIRA DE PESQUISA AGROPECUÁRIA . EMBRAPA. Centro Nacional de Pesquisa de Solos. Manual de métodos de análise de solo. 2.ed. Rio de Janeiro, Ministério da Agricultura e do Abastecimento, 1997. 212p.

FIELD, J.A.; RENEAU, R.B. \& KROONTJE, W. Effects of anaerobically digested poultry manure on soil phosphorus adsorption and extractability. J. Environ. Qual., 14:105107, 1985.

HEDLEY, M.J.; STEWART, J.W.B. \& CHAUHAN, B.S. Changes in inorganic and organic soil phosphorus fractions induced by cultivation practices and by laboratory incubations. Soil Sci. Soc. Am. J., 46:970-976, 1982.

HeCKRATH, G.; BROOKES, P.C.; POUlTon, P.R. \& GOULDING, K.W.T. Phosphorus leaching from soils containing different phosphorus concentrations in the Broadbalk experiment. J. Environ. Qual., 24:904-910, 1995.

HODGKINSON, R.A.; CHAMBERS, B.J.; WITHERS, P.J.A. \& CROSS, R. Phosphorus losses to surface waters following organic manure applications to a drained clay soil. Agric. Water Manag., 57:155-173, 2002.
JACKSON, M.L. Soil chemical analysis. New Jersey, PrenticeHall, 1958. 498p.

McDOWELL, R.W.; CONDRON, LM.; MAHIEU, N.; BROOKES, P.C.; POULTRON, P.R. \& SHARPLEY, A.N. Analysis of potentially mobile phosphorus in arable soils using solid-state nuclear magnetic resonance. J. Environ. Qual., 31:450-456, 2002

McDOWELL, R.W. \& SHARPLEY, A.N. Approximating phosphorus release from soils to surface run-off and subsurface drainage. J. Environ. Qual., 30:508-520, 2001.

MAGUIRE, R.O. \& SIMS, J.T. Measuring agronomic and environmental soil phosphorus saturation and predicting phosphorus leaching with Mehlich 3. Soil Sci. Soc. Am. J., 66:2033-2039, 2002.

MAZUR, N.; VELLOSO, A.C.X. \& SANTOS, G.A. Efeito do composto de resíduo urbano no $\mathrm{pH}$ e alumínio trocável em solo ácido. R. Bras. Ci. Solo, 7:157-159, 1983.

MURPHY, J. \& RILEY, J.P. A modified single solution method for determination of phosphate in natural water. Anal. Chem. Acta, 27:31-36, 1962.

NOVAIS, R.F. \& SMYTH, T.J. Fósforo em solo e planta em condições tropicais. Viçosa, MG, Universidade Federal de Viçosa, 1999. 399p.

OLSEN, S.R. \& WATANABE, F.S. A method to determine a phosphorus adsorption maximum of soils as measured by the Langmuir isoterm. Soil Sci. Soc. Am. Proc., 21:144$149,1957$.

ROBINS, C.W.; FREEBORN, L.L. \& WESTERMANN, D.T. Organic phosphorus source effects on calcareous soil phosphorus and organic carbon. J. Environ. Qual., 29:973978,2000

ROBINSON, J.S. \& SHARPLEY, A.N. Release of nitrogen and phosphorus from poultry litter. J. Environ. Qual., 24:62-67, 1995 .

RON VAZ, M.D.; EDWARDS, A.C.; SHAND, C.A. \& CRESSER, M.S. Phosphorus fractions in soil solution: Influence of soil acidity and fertilizer additions. Plant Soil, 148:175183, 1993.

SHARPLEY, A. \& MOYER, B. Phosphorus forms in manure and compost and their release during simulated rainfall. J. Environ. Qual., 29:1462-1469, 2000.

SHARPLEY, A.; McDOWELL, R.W. \& KLEINMAN J.A. Amounts, forms and solubility of phosphorus in soils receiving manure. Soil Sci. Soc. Am. J., 68:2048-2057, 2004.

SHARPLEY, A.N.; SMITH, S.J. \& BAIN, W.R. Nitrogen and phosphorus fate from long-term poultry litter applications to Oklahoma soils. Soil Sci. Soc. Am. J., 57:1131-1137, 1993.

SOUZA, C.R. Biodisponibilidade e transformações de formas de fósforo em camas de aviário por meio de fracionamento químico e ressonância magnética nuclear do ${ }^{31} \mathrm{P}$. Viçosa, MG, Universidade Federal de Viçosa, 2004. 76p. (Tese de Mestrado)

TOOR, G.S.; CONDRON, L.M.; DI, H.J. \& CAMERON, K.C. Seasonal fluctuations in phosphorus loss by leaching from a grassland soil. Soil Sci. Soc. Am. J., 68:1429-1436, 2004a. 
TOOR, G.S.; CONDRON L.M.; DI, H.J.; CAMERON, K.C. \& SIMS, J.T. Assessment of phosphorus leaching losses from a free draining grassland soil. Nutr. Cycl. Agroecos., 69:167-184, 2004b.

TURNER, B.L. \& HAYGARTH, P.M. Phosphorus forms and concentrations in leachate under four grassland soil types. Soil Sci. Soc. Am. J., 64:1090-1099, 2000.
VETTORI, L. Métodos de análise de solo. Rio de Janeiro, Ministério da Agricultura, 1969. 24p. (Boletim Técnico, 7)

WHALEN, J.K. \& CHANG, C. Phosphorus accumulation in cultivated soils from long-term annual applications of cattle feedlot manure. J. Environ. Qual., 30:229-237, 2001. 